\title{
Bibliometric profile of postgraduate theses in veterinary obstetrics and gynecology in Turkey
}

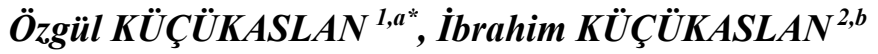 \\ ${ }^{I}$ Dicle Üniversitesi Veteriner Fakültesi Veteriner Hekimliği Tarihi ve Deontoloji Anabilim Dall, 21280, Diyarbakır, Türkiye \\ ${ }^{2}$ Dicle Üniversitesi Veteriner Fakültesi Doğum ve Jinekoloji Anabilim Dall, 21280, Diyarbakır, Türkiye \\ ORCID: 0000-0002-7494-0236 ${ }^{a}$; 0000-0002-3458-4409 ${ }^{b}$
}

\author{
MAKALE BILGISI / \\ ARTICLE \\ INFORMATION: \\ Geliş / Received: \\ 31 Ekim 21 \\ 31 October 21 \\ Revizyon/Revised: \\ 22 Aralık 21 \\ 22 December 21 \\ Kabul / Accepted: \\ 31 Aralık 21 \\ 31 December 21 \\ Anahtar Sözcükler: \\ Bibliyometrik profil, \\ Doğum ve jinekoloji, \\ Lisansüstü tezler, \\ Türkiye, \\ Veteriner hekimliği \\ Keywords: \\ Bibliometric profile, \\ Obstetrics and \\ gynecology, \\ Postgraduate theses, \\ Turkey, \\ Veterinary medicine
}

\section{ABSTRACT:}

The aim of the research is to evaluate the postgraduate theses completed in the field of veterinary obstetrics and gynecology in terms of bibliometric features in Turkey. The material of the study consisted of postgraduate theses completed in this field from 1946 to May 2021 in Turkey. In this context, the data obtained by bibliometric analysis of master's and doctoral theses completed in the field of veterinary obstetrics and gynecology were tabulated in terms of university, year, gender, subject and animal species. In the study, a total of 357 postgraduate theses, which were 143 master's and 214 doctorate, were identified. It was determined that the highest number of master's $(n=27,18.88 \%)$ and doctoral theses $(\mathrm{n}=91,42.52 \%)$ were completed at Ankara University. It was determined that the highest number of postgraduate theses belonged to male researchers (master; $n=102,71.33 \%$, doctorate; $n=159,74.30 \%$ ). It was determined that the highest number of master's theses were prepared between the years 2010-2021, and the highest number of doctoral theses was prepared between the years 2000-2009. When the subject trends were examined, it was determined that both master's and doctorate theses were mainly focused on control of reproduction (master's; $n=43$, $30.71 \%$ and doctorate; $n=48,22.43 \%$ ). Also these theses were mostly studied on cattle (master's; $n=66,47.14 \%$ and doctorate; $n=115,53.74 \%$ ). As a result, it can be argued that the study will shed light on the qualitative and quantitative evaluations to be made regarding the determination of the scientific level of veterinary obstetrics and gynecology postgraduate education.

\section{Türkiye'de veteriner doğum ve jinekoloji lisansüstü tezlerinin bibliyometrik profili}

ÖZET:

$\mathrm{Bu}$ araştırmada, Türkiye'de veteriner doğum ve jinekoloji alanında tamamlanan lisansüstü tezlerinin bibliyometrik özellikler açısından değerlendirilmeleri amaçlandı. Çalışmanın materyalini alanın Türkiye'de ilk doktora tezinin tamamlandığı 1946 yılından Mayıs 2021 tarihine kadar geçen 75 yıllık süre içerisinde tamamlanmış olan tüm yüksek lisans ve doktora tezleri oluşturdu. Bu kapsamda veteriner doğum ve jinekoloji alanında tamamlanan yüksek lisans ve doktora tezlerinin bibliyometrik analizi yapılarak elde edilen veriler üniversite, yıl, cinsiyet, konu ve hayvan türü değisskenleri bakımından tablolar haline getirildi. Calıșmada 143'ü yüksek lisans, 214'ü doktora olmak üzere toplam 357 lisansüstü tezi belirlendi. En fazla sayıda yüksek lisans tezinin $(n=27, \% 18.88)$ ve doktora tezinin $(n=91, \% 42.52)$ Ankara Üniversitesinde tamamlandığ ${ }_{1}$ belirlendi. En fazla sayıda lisansüstü tezin (yüksek lisans; $n=102, \% 71.33$, doktora; $n=159, \% 74.30$ ) erkek araştırmacılara ait olduğu saptandı. En fazla sayıda yüksek lisans tezinin 2010-2021 yılları arasında ve en fazla sayıda doktora tezinin 2000-2009 yılları arasında hazırlandığı belirlendi. Konu eğilimleri değerlendiğinde, hem yüksek lisans hem de doktora tezlerinde ağırlıklı olarak üremenin kontrolü (yüksek lisans; $n=43$, \%30.71 ve doktora; $\mathrm{n}=48, \% 22.43$ ) konusuna odaklanıldığı saptandı. Tezlerde çoğunlukla sığırlar üzerinde çalışıldığı belirlendi (yüksek lisans; $n=66, \% 47.14$ ve doktora; $n=115, \% 53.74$ ). Sonuç olarak, çalışmanın veteriner doğum ve jinekoloji alanı lisansüstü eğitiminin bilimsel düzeyini belirlenmesine ilişkin yapılacak olan kalitatif ve kantitatif değerlendirmelere $1 s ̧ 1 \mathrm{k}$ tutacağı ileri sürülebilir.

How to cite this article: Küçükaslan Ö, Küçükaslan İ. Bibliometric profile of postgraduate theses in veterinary obstetrics and gynecology in Turkey. Vet Hekim Der Derg 2022;93(1):52-58. DOI: 10.33188/vetheder.1016877 


\section{Introduction}

Doctorate education in the field of veterinary medicine started with the doctoral regulation issued one year after the establishment of Ankara Higher Agricultural Institute (HAI) (1933) in Turkey (1). The first doctoral thesis on obstetrics and gynecology at HAI Veterinary Faculty was completed by Hüseyin Erk in 1946 (2, 3, 4). With the enactment of the Law No. 2547, which regulates the functioning of higher education in Turkey in the 1980s, postgraduate education was transferred to newly established institutes (5). In 1980s postgraduate education in the field of veterinary medicine has started to be carried out in cooperation with the faculties under the roof of the "Institute of Health Sciences" (IHS) (6). In Turkey, there are 29 veterinary faculties that actively carry out education, scientific research and publication activities as of May 2021 (7). Among the IHS's of the universities to which these faculties are affiliated, today there are 15 institutes produced graduates from master's programs and 12 institutes from doctoral programs in the field of veterinary obstetrics and gynecology $(8,9)$. There are 10 institutes in the field of obstetrics and gynecology produced graduates from both master's and doctoral programs. IHS's in Uludağ and İstanbul Universities only produced graduates at Ph.D. level. In institutes in Dicle University, Atatürk University, Mustafa Kemal University, Kirıkkale University and Harran University, only master's degree graduates are offered in this field (9). In her bibliography study, Küçükaslan (8) reported that a total of 357 postgraduate theses were completed until May 2021 in this field.

Bibliometric analysis is defined as a quantitative measure of scientific communication and the use of bibliometric analysis enhances the existing data by articulating the knowledge graduates have produced, thus making this knowledge more useful and accessible (10). Bibliometrics was however first used by Pritchard (11) in a publication titled "Statistical Bibliography or Bibliometrics", and then he proposed a new term called "Bibliometrics" which he referred to as "the application of mathematics and statistical methods to books and other media of communication" (12). It is important to examine the studies carried out in any branch of science at certain time intervals, in terms of determining the progress in the discipline. Numerous techniques have been developed to determine the qualifications of scientific journals, conferences and theses. Among these techniques, the most used analysis method is bibliometric analysis (13). To date, there is no research has been found that bibliometric analyzes on Turkish veterinary obstetrics and gynecology postgraduate theses. Therefore, this study was carried out to determine the bibliometric profile of the postgraduate theses in the field of veterinary obstetrics and gynecology in Turkey. In line with this general goal our basic hypotheses and related questions in the research are as follows;

- "There is a numerical increase in postgraduate theses over the years." What is the distribution of postgraduate student theses numbers by years?

- "Postgraduate theses are predominantly prepared by men." What is the gender distribution of graduate students?

- "Postgraduate theses are mostly completed at Ankara University." What is the distribution of postgraduate student theses by universities?

- "These theses are focused on control of reproduction." What is the distribution of the research topics of postgraduate student theses.

- "Postgraduate theses studies are mostly carried on cattle." What is the distribution of postgraduate student theses by animal species.

\section{Material and Methods}

The main material of the research consisted of postgraduate theses completed in the field of veterinary obstetrics and gynecology in Turkey. In the study the reference source named "Bibliography of obstetrics and gynecology postgraduate theses in Turkish Veterinary Medicine (1946-2021)" prepared by Küçükaslan (8) who is one of the authors of this article was used. Full text of materials were accessed from the "National Thesis Center" of the Council of Higher Education internet database (9). In addition, resources related to the subject were also used. In this context, 75 year period from 1946 -when the first doctoral thesis was completed in the field of veterinary 
obstetrics and gynecology in Turkey- to May 2021 were discussed. The population for the study was total 357 postgraduate theses in this field.

The bibliometric method was used to analyze the data in the study. Microsoft Excel spreadsheet was used to organize the data. The bibliographic access points considered when exporting data to a Microsoft Excel spreadsheet are as follows: type of the thesis, university, author gender, dissertation year, research topic and animal species category. No records were excluded from analysis. This created master list was analyzed with Microsoft Excel spreadsheet, and then presented as descriptive data, percentages and tables. When determining the priority topics of the theses, the full texts of the theses were examined as well as the subject headings. In cases where the full text could not be reached, the theses summaries were examined and the priority topics were determined.

\section{Results}

In the study, a total of 357 postgraduate theses (master's $=143$, doctorate $=214$ ) were analyzed. The findings obtained from this research are presented below.

In Table 1, there are findings regarding the distribution of veterinary obstetrics and gynecology master's and doctorate theses by years. Accordingly, it was determined that the highest number of master's theses were made between the years 2010-2021 (70.63\%) and for doctoral theses, it was determined that it was 2000 to 2009 (38.78\%) (Table 1).

Table 1: Distribution of postgraduate theses by years in the field of veterinary obstetrics and gynecology (1946May 2021).

Tablo 1: Veteriner doğum ve jinekoloji alanı lisansüstü tezlerinin yıllara göre dă̆gllmı (1946-Mayıs 2021).

\begin{tabular}{ccccc} 
Years & Doctoral Theses & $\mathbf{\%}$ & Master's Theses & \% \\
\hline $1940-1949$ & 1 & 0.47 & - & - \\
$1950-1959$ & 1 & 0.47 & - & - \\
$1960-1969$ & 2 & 0.94 & - & - \\
$1970-1979$ & 4 & 1.87 & - & - \\
$1980-1989$ & 13 & 6.07 & - & - \\
$1990-1999$ & 44 & 20.56 & 4 & 2.8 \\
$2000-2009$ & 83 & 38.78 & 38 & 26.57 \\
$2010-2021$ & 66 & 30.84 & 101 & 70.63 \\
TOTAL & $\mathbf{2 1 4}$ & $\mathbf{1 0 0}$ & $\mathbf{1 4 3}$ & $\mathbf{1 0 0}$ \\
\hline
\end{tabular}

When, distribution of master's and doctorate theses in veterinary obstetrics and gynecology by universities was evaluated, it was determined that the highest number of master's $(n=27)$ and doctoral theses $(n=91)$ were completed at Ankara University (AU) (Table 2). Also, it was determined that the highest number of postgraduate theses belonged to male researchers (master's, $n=102,71.33 \%$, doctoral, $n=159,74.30 \%$ ). In addition, when the graduation status of female students was evaluated, AU was found to be the university that graduated the most female students from postgraduate programs (master's, $n=9,21.95 \%$, doctorate, $n=26,47.27 \%$ ) (Table 2).

It was found that research topics of graduate theses were focused on the "control of the reproduction" in higher proportions than the other topics both in master's and doctoral theses $30.71 \%$ and $22.43 \%$ respectively. In both master's and doctoral theses, the highest rates after control of reproduction were determined under the topics of infertility and examination methods (Table 3). 
Table 2: Distribution of postgraduate theses by university and gender in the field of veterinary obstetrics and gynecology.

Tablo 2: Veteriner doğum ve jinekoloji alanı lisansüstü tezlerinin üniversite ve cinsiyete göre dă̆llımı .

\begin{tabular}{|c|c|c|c|c|}
\hline \multirow{2}{*}{ University } & \multicolumn{2}{|c|}{ Master's Theses } & \multicolumn{2}{|c|}{ Doctoral Theses } \\
\hline & Female & Male & Female & Male \\
\hline Adnan Menderes University & 4 & 7 & - & 4 \\
\hline Afyon Kocatepe University & 3 & 12 & - & 4 \\
\hline Ankara University ${ }^{*}$ & 9 & 18 & 26 & 65 \\
\hline Atatürk University & - & 4 & - & - \\
\hline Dicle University & 1 & 1 & - & - \\
\hline Erciyes University & 5 & 8 & 1 & 2 \\
\hline Furat University & 1 & 6 & 1 & 16 \\
\hline Harran Üniversitesi & 2 & 3 & - & - \\
\hline İstanbul University Cerrahpaşa ${ }^{\dagger}$ & - & - & 16 & 24 \\
\hline Kafkas University & 2 & 7 & 1 & 2 \\
\hline Kırıkkale Üniversitesi & 1 & 1 & - & - \\
\hline Burdur Mehmet Akif Ersoy University ${ }^{\dagger}$ & 3 & 8 & - & 1 \\
\hline Hatay Mustafa Kemal University ${ }^{\dagger}$ & 5 & 8 & - & - \\
\hline Ondokuz Mayıs University & 2 & 5 & 2 & 1 \\
\hline Selçuk University & - & 7 & 3 & 27 \\
\hline Bursa Uludağ University ${ }^{\dagger}$ & - & - & 4 & 11 \\
\hline Yüzüncü Yıl University & 3 & 7 & 1 & 2 \\
\hline TOTAL & 41 & 102 & 55 & 159 \\
\hline
\end{tabular}

Table 3: Distribution of postgraduate theses by research topics in the field of veterinary obstetrics and gynecology.

Tablo 3: Veteriner doğum ve jinekoloji alanı lisansüstü tezlerinin araştırma konularına göre dă̆glımı

\begin{tabular}{|c|c|c|c|c|}
\hline & \multicolumn{4}{|c|}{ Type of Thesis } \\
\hline & \multicolumn{2}{|c|}{ Doctoral } & \multicolumn{2}{|c|}{ Master's } \\
\hline & $\mathbf{n}$ & $\%$ & $\mathbf{n}$ & $\%$ \\
\hline Biotechnology & 25 & 11.68 & 4 & 2.86 \\
\hline Fertility & 15 & 7.01 & 9 & 6.43 \\
\hline Infertility & 40 & 18.69 & 22 & 15.71 \\
\hline Physiology of Pregnancy & 9 & 4.21 & 6 & 4.29 \\
\hline Examination Methods & 26 & 12.15 & 17 & 12.14 \\
\hline Mammary Health & 24 & 11.21 & 17 & 12.14 \\
\hline Gynaecological Surgery & 2 & 0.93 & 10 & 7.14 \\
\hline Control of Reproduction & 48 & 22.43 & 43 & 30.71 \\
\hline Reproductive Anatomy - Physiology & 18 & 8.41 & 9 & 6.43 \\
\hline Neonatology & 5 & 2.34 & 1 & 0.72 \\
\hline Mammary Tumours & 2 & 0.93 & 2 & 1.43 \\
\hline TOTAL & 214 & 100 & 140 & 100 \\
\hline
\end{tabular}

\footnotetext{
${ }^{*}$ Since HAI was affiliated to Ankara University in 1948, it was included in this section. Only one person (Hüseyin Erk) from HAI has prepared a doctoral thesis.

${ }^{\dagger}$ The previous names of these universities are as follows: İstanbul University, Mehmet Akif Ersoy University, Mustafa Kemal University and Uludağ University.
} 
There are findings regarding the distribution of veterinary obstetrics and gynecology master's and doctorate theses topics according to animal species. Accordingly, it was determined that most of the postgraduate theses were done on cattle both in master's and doctoral theses $47.14 \%$ and $53.74 \%$ respectively (Table 4 ).

Table 4: Distribution of postgraduate theses by animal species in the field of veterinary obstetrics and gynecology.

Tablo 4: Veteriner doğum ve jinekoloji alanı lisansüstü tezlerinin hayvan türlerine göre dağılımı .

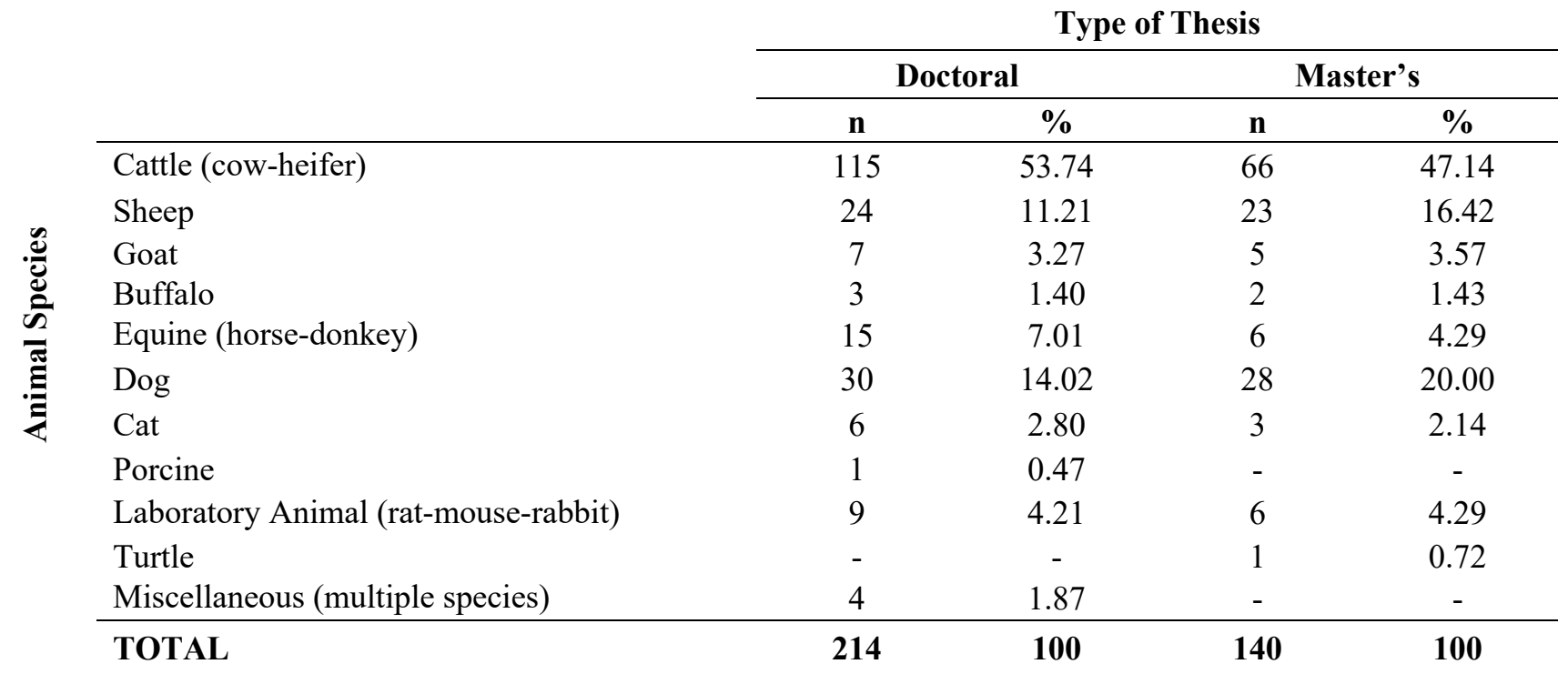

\section{Discussion and Conclusion}

Researches in the field of veterinary obstetrics and gynecology is constantly growing in the scientific literature, including books, journal articles, congress proceedings, postgraduate theses and others (2). The fact that a total of 357 postgraduate theses were given in this field in the study shows that there is an important development in terms of scientific productivity. Especially after the year of 2000, it is seen that there is a visible increase in the theses completed in this field.

Ankara University has the highest number of completed postgraduate theses both in master's and doctorate program when the distribution of graduate theses was evaluated by universities. This situation can be explained by the fact that this university has the country's first veterinary faculty.

Küçükaslan (2) reported that the first master's program in this field was opened in 1989. In the years following this date, there has been an increase in the number of master's graduates. Especially in the last ten years, the rapid increase in master's graduates can be explained by the fact that institutions provide the necessary conditions to open the program and academicians prefer this. In addition, the preparation of 143 master's theses in total is one of the indicators of the contribution and scientific developments to the related field. It can be argued that the increase in the number of academicians along with the staffing in the field of veterinary obstetrics and gynecology is also reflected in the number of theses.

Examining the postgraduate theses in this field in terms of gender is another important point of the research. Başağaç Gül et al. (14) reported that veterinary medicine has historically been a male-dominated profession and that there has been a rapid increase in the number of female graduates in developing countries. In the study, it was determined that the most master's thesis belonged to male researchers (master, $n=102,71.33 \%$, doctorate, $n=159$, $74.30 \%$ ). The numerical status of female graduates in the study also supports this view. Since the field of obstetrics and gynecology is among the clinical sciences, it can be argued that this situation may affect the employment of 
women or the number of female veterinarians who prefer this field.

It was determined that the highest number of postgraduate female students graduated from AU (master's, $\mathrm{n}=$ $9,1.95 \%$, doctorate, $n=26,47.27 \%$ ). Küçükaslan et al (15) also reported that most of first female veterinarian academicians in Turkey started to work in AU and this is due to the fact that this institution is the oldest veterinary faculty in Turkey.

When the research topics of the doctoral theses were evaluated, it was determined that the most studies were done on control of reproduction $(n=48,22.43 \%)$ and most of the master's theses were done on cattle both in masters $(n=66,47.14 \%)$ and doctoral theses $(n=115,53.74 \%)$. According to Turkish Statistical Institute (16) data, in Turkey cattle population was increased from 9.803 .489 to 17.965 .482 in a twenty years period since 2002 with an increase in meat and milk production. According this, in parallel with the increase in the population every year, the number of food animals is increasing. When the causality between the number of cattle and the population was examined, a positive relationship was determined between them (17). The reason why most of the theses are both on reproductive control issues and on cattle may be occurred due to the fact that dairy herds are established for economic profitability and the most important indicator of economic profitability is the fertility of the herd, and therefore, producers and veterinarians should be more concerned with the fertility and reproductive problems in the herd reported by several authors $(18,19,20,21,22)$. It is seen that a similar situation has been determined by Viriezen et al (23), where the studies are predominantly conducted on cattle.

In conclusion, it is thought that this study will guide the researches by providing preliminary information to the researchers in terms of the qualifications of the postgraduate theses on veterinary obstetrics and gynecology. Also conducting a more in-depth research on female scientists in the field of veterinary obstetrics and gynecology can be recommended in terms of contributing to women's studies. For example, determining which research areas and which animal species women tend towards in their academic studies provides a more detailed contribution to women studies. Determining the publication and citation rates of postgraduate theses prepared in the field of veterinary obstetrics and gynecology in journals is another issue that can be recommended to researchers. Thus, it will be possible to examine whether this valuable research that has lasted for years has been delivered to a wider community.

\section{Conflict of Interest}

The authors declared no conflict of interest.

\section{Funding}

During this study, any pharmaceutical company that has a direct connection with the subject of the research, a company that provides and / or produces medical tools, equipment and materials, or any commercial company, during the evaluation process of the study, no financial and / or moral support was received.

\section{Authors' Contributions}

This section specifies the exact contributions of each author in a narrative form.

Motivation / Concept: Özgül Küçükaslan

Design: Özgül Küçükaslan, İbrahim Küçükaslan

Control/Supervision: Özgül Küçükaslan, İbrahim Küçükaslan

Data Collection and / or Processing: Özgül Küçükaslan, İbrahim Küçükaslan

Analysis and / or Interpretation: Özgül Küçükaslan, İbrahim Küçükaslan

Literature Review: Özgül Küçükaslan, İbrahim Küçükaslan

Writing the Article: Özgül Küçükaslan, İbrahim Küçükaslan

Critical Review: Özgül Küçükaslan, İbrahim Küçükaslan 


\section{Ethic Decleration}

An ethical statement was received from the authors that the data, information and documents presented in this article were obtained within the framework of academic and ethical rules, and that all information, documents, evaluations and results were presented in accordance with scientific ethical and moral rules.

\section{References}

1. Turkish Official Gazette. Ankara Yüksek Ziraat Enstitüsünün Doktora Talimatnamesi. No: 2832, 18 October 1934.

2. Küçükaslan Ö. Türk veteriner hekimliğinde doğum ve jinekoloji tarihi üzerine araştırmalar. Doktora Tezi. Ankara Üniversitesi Sağlık Bilimleri Enstitüsü, Ankara, 2012.

3. Küçükaslan Ö, Başağaç Gül RT. A study on the obstetrics and gynaecology in Turkish veterinary education. Ankara Üniv Vet Fak Derg 2014; 61(1): 21-28.

4. Küçükaslan Ö, Küçükaslan İ. A study on the life and works of Prof. Dr. Hüseyin Erk. Vet Hekim Der Derg 2015; 86(1): 10-21.

5. Turkish Official Gazette. Yükseköğretim Kanunu. No: 17506, 6 November 1981.

6. Başağaç Gül RT, Özkul T, Akçay A, Melikoğlu B. Türkiye'de veteriner hekimliği alanında lisansüstü eğitim. Ankara Üniv Vet Fak Derg 2010; 57: 19-24.

7. ÖSYM. Yükseköğretim kurumları sınavı (YKS) yükseköğretim programları ve kontenjanları kılavuzu 2020. Available from: URL: https://dokuman.osym.gov.tr/pdfdokuman/ 2020/YKS/tkilavuz13082020.pdf. (Accessed October 11, 2021).

8. Küçükaslan Ö. Bibliography of obstetrics and gynecology postgraduate theses in Turkish veterinary medicine (1946-2021). USBAD Uluslararas1 Sosyal Bilimler Akademi Dergisi 2021; 3(6): 1245-1291.

9. YÖK. Ulusal Tez Merkezi, [cited 2021 May 10]; Available from: URL: https://tez.yok.gov.tr/UlusalTezMerkezi/

10. Macauley $P$, Evans T, Pearson M, Tregenza K. Using digital data and bibliometric analysis for researching doctoral education. Higher Education Research \& Development 2005; 24(2): 189-199.

11. Pritchard A. Statistical bibliography or bibliometrics? Journal of Documentation, 1969; 25(4): 348-349. [cited 2021 July 24]; Available from: URL: https://www.researchgate.net/publication/236031787_Statistical_Bibliography_or_Bibliometric

12. Bilson APKE, Alemna AA, Badu EE. A bibliometric analysis of theses at the school of nuclear and allied sciences, University of Ghana, Legon. Library Philosophy and Practice (e-journal) 2019; 2567. [cited 2021 July 24]; Available from: URL: https://digitalcommons.unl.edu/cgi/viewcontent.cgi?article=6009\&context=libphilprac

13. Kozak N. Türkiye' de akademik turizm literatürünün gelişim süreci üzerine bir inceleme. DAÜ: Turizm Araştırmaları Dergisi 2000; 1(1): 15-55.

14. Başağaç Gül RT, Özkul T, Akçay A, Özen A. Historical profile of gender in Turkish veterinary education. JVME 2008; 35(2): 305-309.

15. Küçükaslan Ö, Başağaç Gül RT, Ünsal A. The first female academicians in Turkish veterinary education. Ankara Univ Vet Fak Derg 2017; 64(4): 255-260.

16.TUIKK. Hayvansal Üretim İstatistikleri 2021, [cited 2021 October 10]; Available from: URL: https://data.tuik.gov.tr/Kategori/GetKategori?p=Tarim-111.

17. Çelik Ş. Causality relationship between cattle numbers and population in Turkey. ADYUSCI 2015; 5(1): 80-93 .

18. Alan M, Taşal İ, Çetin Y, Saban E, Uyar A. Prediction of postpartum ovarian activity by serum progesteron levels and clinical observations in cows. YYÜ Vet Fak Derg 2000; 11: 60-4.

19. Aslan S, Gümen A. Fertilite Kontrol Programları. In: Semacan A, Kaymaz M, Fındık M, Rişvanlı A, Köker A, editor. Çiftlik Hayvanlarında Doğum ve Jinekoloji. 2. ed. Malatya: Medipress Matbaacılık; 2015. p.421-454.

20. Bekyürek T. The effect on the fertility of reproductive management in cows. Turkiye Klinikleri J Vet Sci Obstet Gynecol-Special Topics 2017; 3(3): 179-96.

21. Dinç DA. Süt ineği işletmelerinde sürü sağlığı ve reprodüktif sürü sağlığı kavramı ve veteriner hekimin rolü. Türkiye Klinikleri J Vet Sci Obstet Gynecol 2015; 1(1): 1- 16.

22. Thatcher WW, Bartolome JA, Sozzi A, Silvestre F, Santos JE. Manipulation of ovarian function for the reproductive management of dairy cattle. Vet Res Commun 2004; 28: 111-9.

23. Vriezen R, Sargeant JM, Vriezen E, Reist M, Winder CB, O'Connor AM. Systematic reviews and meta-analyses in animal health, performance, and on-farm food safety: A scoping review. Animal Health Research Reviews 2019; 20: 116-127. 